\title{
Translations from the Chinese World Map of Father Ricci (Continued)
}

\section{Author(s): Matteo Ricci and Lionel Giles}

Source: The Geographical Journal, Vol. 53, No. 1 (Jan., 1919), pp. 19-30

Published by: geographicalj

Stable URL: http://www.jstor.org/stable/1780397

Accessed: 20-06-2016 10:49 UTC

\section{Your use of the JSTOR archive indicates your acceptance of the Terms \& Conditions of Use, available at}

http://about.jstor.org/terms

JSTOR is a not-for-profit service that helps scholars, researchers, and students discover, use, and build upon a wide range of content in a trusted digital archive. We use information technology and tools to increase productivity and facilitate new forms of scholarship. For more information about JSTOR, please contact support@jstor.org.

The Royal Geographical Society (with the Institute of British Geographers), Wiley are collaborating with JSTOR to digitize, preserve and extend access to The Geographical Journal 
expect Persia to reform herself without any assistance from outside. If we are to assist her in any way, let us hope, at any rate, that we get an administration out there which is strong enough to initiate the necessary reforms, and wise and tactful enough to deal with all the rocky problems of Persian politics ; strong enough, if need be, to face the Westminster politicians. If we could only find some one who would be to Persia what Cromer was to Egypt, then great benefit would accrue. The line of development in Persia in the future, as has already been indicated by Colonel Napier and other speakers, is the development of communications. For my own part, I am not astonished to hear that motor traffic is within reasonable possibility over, at any rate, some of the Persian roads; and I believe that the roads Colonel Napier has described are some of the worst. Fifteen or twenty years ago I pointed out-and I think that our old friend Sir Percy Sykes entirely agreed with me-that from Quetta to Kerman, and from Kerman to Kirmanshah, you can run a motor almost without any difficulty and without road-making. It has been done, and consequently I agree with Sir Valentine Chirol when he says that in future, in spite of all the possibilities that have been opened out for railway construction in different parts of Persia, the probable future of trans-Persian communications will be in motor service. But there is yet one other means of transport that is as quick as motor ; indeed, much faster and as direct and possible, and that is the aeroplane. I fully believe that it will not be very long -I do not think it will be two years-before we have a regular aeroplane service across Persia to India. If that happens a very great response will be made, because it is by the introduction of travellers into Persia, by the opening up of Persia to general investigation and exploration, that that country will be most benefited. I will not detain you further, but will just ask you to join in a very hearty vote of thanks to Colonel Napier for his most excellent address to-night.

\title{
TRANSLATIONS FROM THE CHINESE WORLD MAP OF FATHER RICCI
}

\author{
Lionel Giles, M.A., D.Litt.
}

(Continued from Vol. $52, p .385$.)

$\mathrm{M}^{\mathrm{A}}$ ANY other points in Ricci's geography of the Far East are worthy of comment. His island of Formosa. (called "Great Loochoo") is reasonably accurate both in size and position-a great improvement on the Ambrosiana map. The "Little Loochoo" are just north of it, while the main Loochoo group is simply called the Five Islands. European maps showed Formosa as a small island lying between "Lequio minor" (in the south) and Lequio maior (in the north).

The notes on Korea and Japan run thus :

Korea (Chao-hsien) was a feudal State founded by Viscount Chi [12th cent. B.c.]. Under the Han and T'ang dynasties it was a province of China, and at the present day it is the chief of the tribute-bearing dependencies. Of old, it was divided up into several kingdoms-San-han, Wei-mo, P'o-hai, Hsichih, Chia-lo, Fu-yü, Hsin-lo, Po-chi, Tan-lo, etc.-but now all of these have been incorporated into a single State. 
Japan is a large island $*$ in the sea, $3200 l i$ in length and not more than $600 \mathrm{li}$ in breadth. It is now divided into 66 departments, each of which has its own independent ruler. Brute force is the controlling factor, and although there is a sovereign over the whole country, the real power is always in the hands of his vassals. The people are much more addicted to the arts of war than of peace. $t$ The country produces silver and iron and excellent lacquer. If the king has a son, he abdicates in his favour when the latter attains the age of 30. In this country, very little value is attached as a rule to precious stones gold and silver and old porcelain are esteemed much more highly.

In the inscription dealing with India, some of the characters are illegible, but I can make out the following:

Ying-ti-ya (India) is a general name for what the Chinese call "Small Western Ocean," this name being derived from its many rivers. One half lies on this side of the $A n-i$ River (Ganges), the other half beyond it. The world's precious stones and valuables come from this country : fine cloth, gold and silver, spices, putchuck, frankincense, drugs, black wood (?), etc., are all found here. Hence all the year round it is frequented by traders from east and west. The natives are dark-skinned [... In the south, few clothes are worn. [There is no ... ] leaves of trees are made into [...]. Iron styles are used (for writing) instead of brushes. The language spoken by the rulers of the country is different from that of the places [that they govern?]. Wine is made out of coconuts ; of the five grains, only rice (?) is [. . . ] abundant. Among the rajahs, the succession to the throne is never hereditary, but they make their sisters' sons their heirs. Their own sons are granted an allowance $[\ldots]$ and that is all.

Bengal is limited to a very narrow strip of territory east of the Ganges, which runs almost due south. It is described as "the ancient Hsin-tu province, that is to say, eastern Yin-tu." Besides these names for India, we find in the north "Hindustan" and "Western T'ien-chu country." Wo-ya stands for Goa, the headquarters of the Jesuit missionaries in the East, but I cannot make much of the half-obliterated legend on the left. The following scraps may possibly afford some clue :

... not drink ... not eat . . . fixed colour. Meet colour borrow ... as a light ; only (they are) unable to change the red and white colours.

The beginning of the inscription on Chiu-chiang (Old Harbour) on the west coast of the Malay peninsula is also hard to decipher, but it appears to be stated that this was a great emporium for the inhabitants of the South Seas (Chu-fan). It continues :

The people along the sea coast build rafts and make dwelling-houses, covering them in with coconut leaves. When they move, they simply pull up the poles and carry their houses with them (?) The soil is twice as fertile as

* This statement does not agree with the map, on which Japan is correctly represented as consisting of four main islands. We must conclude that Japan was shown as a single island in the first or second edition, as it is in the Ambrosiana map, and that by an oversight the legend remained unaltered when the correction was made.

$\uparrow$ Chau Ju-kua, curiously enough, says exactly the opposite (p. I7I): "In this country the people are not accustomed to fighting." 
other lands. They have a wine made from the ni-po tree, which is nicer than coconut wine. Neighbouring countries like Chan-ch'êng, Ta-ni, etc., all have this drink.

Chiu-chiang is another name for San-fo-ch'i, generally identified with Palembang in Sumatra (see 'Chau Ju-kua,' p. 63). But both here and in the Ambrosiana map $S a n-f o-c^{\prime} i$ is placed in the middle of the Malay Peninsula. This raises an interesting question which $I$ have no space to enter upon here. The wine referred to is nipa arrack (op. cit., p. 64).

P'êng-heng is on the eastern seaboard of the peninsula, which tends to confirm its identification with Pahang, though the Ming Wai Shih places it west of Siam, and Gerini on the north coast of Sumatra. Just below is the country $T a-n i$, on which there is the following note:

In $T a-n i$ there occurs an extremely large bird called $O-m a$. It has wings but cannot $\mathrm{fly}$; its feet are like those of a horse, and it runs very fast, so that a horse cannot overtake it. Its feathers can be made into helmets [and its eggs ?] are also thick and large enough to be made into goblets [. . .].

O-ma is obviously the Portuguese word for ostrich, "ema," which is said to have been applied by the early navigators to the ostrich-like birds of both East and West, e.g. to the cassowary of Ceram (Casuaris galeatus) in the Malay Archipelago, whence a specimen was brought home by the Houtmans, who obtained it during the first Dutch voyage to the East Indies (see Lodewycksz's narrative, Linschoten Soc. edition, pp. I 34, I68, and a picture of the bird on plate 30 ). This is the earliest mention of the cassowary found by Mr. Heawood, to whom I am indebted for the above information.

"Chan-ch'êng, the ancient Lin-i, which produces ebony,"* is immediately south of $P^{*} \imath-k a n$, which is itself south of Annam. This conflicts with the views of Hirth and Rockhill, who identify Chan-ch'êng (or Champa) with Annam, and $P^{\prime} u-k a n$ with Pagān on the Irawadi.

Malacca abounds in flying dragons which coil round trees. They are not more than 4 or 5 feet long, and men often shoot them.

Sumatra is called $S u-m e ̂ n-t a-l a$, but

the old name for this island was Ta-po-pa-na (Taprobana). It is [. . . 40 o li in circumference, and has seven kings ruling over it. The products are gold, elephants' tusks, and a great variety of spices.

The description of Borneo is almost illegible, but it is stated that the country is "blazing hot and subject to frequent storms," and that the towns are built of wood. On a large island to the east of $S \hat{e}-l i-p$ " $i$ (Celebes), I find the name Shih-li-po-ssü, which seems to represent ŚriBhōja or Serboza, the old Arab name for Sumatra. This island forms one of a group entitled "region of $M a-l u-k u$ " (Moluccas), concerning which there is the legend:

* This statement may be derived from Marco Polo, who says there were vast forests of bonus (ebony) in Champa : see Yule and Cordier's edition, vol. 2, pp. 250, 252. 
This land possesses none of the five grains, but only produces the sha-ku rice tree, the bark of which yields a powder which does duty for rice.

Sha-ku is the Malay "sagu" or sago, the manufacture of which is described by Chau Ju-kua (p. 84).

Still further east is the island $P a-p u-y a-s s \breve{h-o b v i o u s l y ~ P a p u a, ~ a l t h o u g h ~}$ separated by a fairly wide channel from the huge promontory of the Southland which represents New Guinea. This latter country

is called New Guinea because it is similar in shape and appearance to Guinea in Africa. Europeans have only recently arrived in this country, hence it is not yet known for certain whether it is a piece of the continent or an island.

Plancius has a similar note; but, according to Herrera and Galvano,

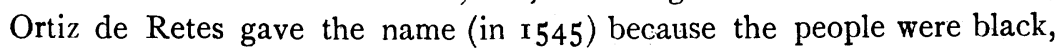
like those of Guinea, and had frizzled hair.

On the north coast of New Guinea is the Hsien* Ou-zun-ssiu-ting River, or the "River of St. Augustine," so named by Ortiz de Retes, who there took possession of New Guinea for the King of Spain. It is marked on most maps of the period, including one of Plancius' smaller maps (reproduced as Kaart 7 of "De Oude Weg naar Indië om de Kaap," Amsterdam, I9I5); and just south of the Tropic of Capricorn, on the rgoth meridian, is the "Peak of Saint Ou-wu-ting," a curiously similar name which $I$ have not been able to identify.

"Great Java, or Ho-ling, otherwise known as Shê-p`o," has the following legend attached :

Java: Soldiers of the Mongol Empire came here and carried off (?) the king. Vast numbers of merchant vessels trade with this country, which has riches in abundance. It exports silver, pearls and precious stones: mother-ofpearl shell, cornelian, rhinoceros horn, ivory, putchuck, etc., are all found here.

Between Java and Ti-mu (Timor) we read that

islands are very numerous, rendering navigation very difficult. In these parts are produced sandalwood, cloves, "gold-and-silver incense," $\dagger$ benzoin, sapanwood, pepper and flake camphor.

"Java the Less," which is Marco Polo's name for Sumatra, is placed by Ricci, as by Mercator, in the centre of a great bay in the Southern Continent. It contains the name Fan-su-êrh, which is the Fansur of mediæval Arab travellers, also given by Mercator. In $M a-l i-t u$, on the west coast of this bay, we have the Maletur of Plancius and others (S. lat. $20^{\circ} 30^{\prime}$, E. long. $148^{\circ} 3^{\prime}$ ), "which aboundeth in all manner of spices." Like "Beach," referred to above, it is a corruption of one of Polo's names - "Malaiur" on the island of Bintang.

* A word meaning " an immortal," always used by Ricci for "Saint."

+ According to Hirth and Rockhill (op. cit., p. 198), this is sweet benzoin. 
In recent years a Castilian ( $K a$-hsi-lang) ship was driven by stress of weather to this coast; but we are only told the breadth and extent of the country, and none of its products.

This statement is of interest in connection with the disputed question of the discovery of Australia in the sixteenth century. Ricci marks $K a-h s i-l a n g$ as a province in the south of Spain, but I do not know what it could stand for except Castile.

Further south is Po-ya-ch'i, and the legend :

Few have reached these southern regions, and consequently there is still no information about the people and things there.

The size of the Philippines is very much exaggerated : there are eight large islands in the group, namely Luzon (with Manila marked), Wo-shan (Recumbent Mountain) Island, Ma-ta-yin, Ya-lai-sha, Chio (Horn) Island, Fei-li-p̧i-na (Philippina), Pa-na-ma, and Mindanao. Of these, only Luzon is named in the Ambrosiana map. The "Robber Islands" (Ladrones) and $C h^{c} a-m a-\hat{e} r h$ Islands are shown as one group. Further out in the Pacific are the Coral Islands :

The coral tree grows at the bottom of the sea ; its colour is green and its substance soft. It bears white seeds, which are caught in a fine-meshed net $[\ldots]$.

Nearer the coast of America we find the Unfortunate Islands :

When Mo-wa-la-ni (Magellan) passed these islands, he found there no human being nor other living creature, and therefore he named them the Unfortunate Islands.

This note occurs also in Plancius. The islands are shown on Mercator's map of 1569 . The inscriptions in North America are, as one would expect, comparatively few in number. Of Alaska or North-West Canada, just below the Arctic Circle, it is stated that

this land is very vast in extent and therefore produces great numbers of wild horses, mountain cattle and sheep. The oxen all have a fleshy hump on the back similar in shape to that of the camel.

Plancius says : "This country is desert and plaine, in which are many wild horses and oxen with high backs like camels, and wild sheep. . . ." Mr. Heawood tells me that this statement appears, in part, on other maps, but he has found none previous to Plancius which speaks of the humped oxen (bison?).

The great lake connected on the one hand with the Arctic Ocean and on the other with the system of St. Lawrence is Ko-ni-pai-ss $\breve{u}$ (Conibaz):

The waters of this vast lake are fresh, but it has not yet been ascertained how far its [. . .] extend. Embarking here, a man may sail along it as far as the country of Sha-wa-nai (Saguenay, which is marked just south of the lake). 
Plancius, following Mercator :

This is a great lake or sea of fresh water, the limits whereof are unknowne as they of Canada do say, and as they have heard by relation of those of Saguenay . . . Alongst this river a man may saile very commodiously towards the country of Saguenay.

To the east, near the source of the $K_{0-j u}$ (Cogib) River, we read :

Above this region no man has yet penetrated, so that nothing is yet known about the inhabitants or products.

The name $K a$-na-ta (Canada) appears to be restricted to a small region near the centre of the continent. But there is also the following note:

From "Husbandman's Land" to the Land of Flowers, the general name of the region is Kan-na-t"o-êrh, but each country has its own name. The inhabitants are kindly and hospitable to strangers. In general, they make their clothes out of skins, and are fishermen by occupation. The people living in the mountains kill one another all the year round, and spend their time in fighting and robbery. They feed exclusively on snakes, ants, spiders, and other creeping things.

The whole of this legend is a condensation of Plancius. Nung Ti (Land of the Husbandman) is a translation of "Terra de Laborador," now Labrador. The most plausible explanation of the name, according to Mr. Heawood, is that given by Ernesto de Canto, namely that it was derived from "João Fernandes, lavrador da Ilha Terceira," who is said to have sailed with Cabot and to have afterwards been associated with British merchants for discovery in this part of the world. Ribero's map of 1529 has "Tiera del Labrador," and Desceliers' of I 546 "Terre $d u$ Laboureur." The Land of Flowers is of course Florida. The Ambrosiana, unlike the R.G.S. map, places this a long way north of the peninsula.

Mo-shih-k $k^{\prime} o$ (Mexico) produces birds' feathers of divers colours, which the people arrange as ornaments. The mountains, rivers, men, and things are all $[$. . . ].

The inner portion of the Gulf of California is called the Eastern Red Sea (as opposed to the Western Red Sea between Arabia and Africa), though further south we find the name Kio-li-fu-êrh-ni applied to both the gulf and the peninsula. Still further south is the island $Y a-n u-p$ " $i-y a-t a$, which is "La Anubiada" of Mercator and Ortelius, and "La Nublada" (Cloudy Island) of earlier map-makers.

In Central America we may note Wa-ti-ma-la (Guatemala) and Yii-hot'ang (Yucatan).

In South America there is much interesting matter, for the elucidation of which I am largely indebted to Mr. Heawood. The general account runs as follows:

South America is now divided into five countries: (I) $P^{6} 0-l u$ (Peru), after a river of that name; (2) Golden $K a-h s i-l a$ (Castilla), so called from the great 
quantities of gold and silver it produces ; $P^{\prime}$ o.pa $y a \cdot n a$ after a great provincial city (Popayán); (4) Chih-li (Chile), an ancient name; (5) Po-hsi-êrh (Brazil), that is, what in China is known as su-mu (sapan-wood). $\dagger$ South of these five countries there is also the region of Pa-ta-wên (Patagonia), where the people are 8 feet high ; hence it is called the land of giants. They have no writing, but carry on their dealings by means of knotted cords (quipo).

The "Nameless Islands," also marked by Mercator and others, may be the Galapagos, though they are a considerable distance south of the equator. A more flagrant blunder is the latitude assigned to Cocos Island, which is shown almost on the Tropic of Capricorn, instead of several degrees north of the Equator. The name "Sea of Peru," as in the Ambrosiana, is given to this part of the Pacific.

Brazil : the name means sapan-wood. The natives of this country build no houses, but live in holes which they make in the ground. They are fond of eating human flesh-of males only, not of females-and weave their garments out of birds' feathers.

The Amazon bears the name $M a$-lang-zên, evidently a transcription of "Maragnon." Not far from its mouth is a tributary flowing out of the "Gold-fish Lake" on the south. The lake corresponds to the "Eupana" of contemporary Dutch maps, which has been traced by Mr. Heawood to a manuscript Portuguese map of ${ }^{2} 5^{6} \mathrm{r}$ by Bartolomeu Velho, where it is made to discharge in four different directions, one being, as in Ricci, towards the Lower Amazon. It seems to have been connected with the El Dorado that was in all men's minds, for in De Jode's atlas of 1593 a lake in a roughly similar position, though discharging to the south only, is marked "Laguna del Dorado." As dorado was also the name of a fish (the "dying dolphin" of the poet), it is pretty clear that Ricci's name for the lake was due to his confusing the two meanings of this word.

South of Gold-fish Lake is another legend on which light has been thrown by Mr. Heawood :

In this country there is an animal named hai, which has never been seen to eat or drink.

Plancius has a notice of the same animal, though he places it further south than Ricci does: "This beast is called of some Haute, but of a certaine people of Brasill it is called Haye, which beast was never seene to eate or drinke, as some write, and therefore some thinke that she liveth without meate or drinke, onely by the Ayre."

* "Castilla del Oro" applied originally to part of Panama, but was extended to cover much of rorth-west South America. In spite of the statement of Garcilaso de la Vega ('Commentaries,' I. vii.) that it referred to a castle built by Nicuesa, it has been generally understood as meaning "Golden Castile."

$\dagger$ Sapan-wood (Casalpinia sappan) was known as brazil-wood in Western mediæval commerce; this name was afterwards transferred to the hard red wood of similar species found in South America, and thence to the country. Chau Ju-kua (p. 2I7) says of sapan-wood: "When the bark is removed and the wood dried in the sun, it is of a deep red colour and may be used in dyeing purple." 
The animal in question must be the ai (aye-aye) or three-toed sloth of the natural history books. The Concise Oxford Dictionary explains its name as representing its cry. In Oviedo's account of the West Indies, as reproduced in Ramusio's Collection (vol. 3, I606 edition, fol. 47), there is a description of the Cagnuolo leggiero, which is evidently the Sloth, and, with equal certainty, Ricci's hai. Its cry is said to resemble $h a h a h a h a$ $h a h a$, and it is stated that one kept by the writer in captivity ate nothing and appeared to live on air. This was the general opinion, because it always held its head and mouth towards the quarter whence the wind blew.

\section{A little to the east of the lake}

there is a beast whose upper part is like a fox and whose lower part is like a monkey, with human feet and the ears of an owl. Under its belly there is a skin (pouch) which can be expanded or contracted, thus enabling its young to rest comfortably therein.

This animal, described in similar terms by Plancius, may perhaps be identified with the largest American species of opossum, Didelphys marsupialis, of which a variety (D. $m$. cancrivora or crab-eating opossum) occurs in South America and seems to have been the one first brought to Europe by the Pinzons in 1499 (see Peter Martyr, 'Decades,' I, Bk. 9). Other South American forms belong to the genus Metachirus, but most of these lack the pouch. Both the above animals are described and figured in Thevet's rare work 'Les Singularitez de la France Antarctique' ( $155^{8}$ ).

In the region of the River $T s^{\prime} a o-n a-f e i-s o$, which is presumably Rio S. Francisco under a different name,

men sleep without beds or mattresses, but make nets out of knotted cords $[\ldots]$ These they suspend from trees [...] and recline in them. On the march they are used like sedan-chairs.

A map engraved by J. van Doetichem in ${ }^{5} 55$ (of which Plancius may quite well have been the author and which is one of the first Dutch maps to give the name Eupana) has a picture of the marsupial mentioned above, with a legend describing it in terms almost identical with those of Plancius in his big map; also a picture of a hammock slung between trees. The Carib word hamac was heard by Columbus during his first voyage in 1492

Peru contains two legends, the first near Lima on the sea-coast; the second further inland:

This land, though not low-lying, has a naturally damp climate and reaps abundant harvests.

The people of this country are ignorant of agriculture, and live in idleness on the numerous fruits which grow there without cultivation. The country produces a perfume called $p a-\hat{e} r h-s o-m o$. This is an oil which flows from a tree when the latter is slit with a knife. Smeared on corpses, it keeps them from decaying. The place where the knife has cut, having yielded its juice, forthwith heals up again. This perfume is also found in Judæa. 
Pa-êrh-so-mo is doubtless the rendering of "balsam"-the product of various trees of the order Burseracee found both in America and the East. The kind probably yielding the balm-of-Gilead was said by Pliny (Bohn's version, vol. 3, p. I47) to have been "bestowed by Nature only upon the land of Judæa." In Acosta's ' Natural and Moral History of the Indies' (Hakl. Soc. Edition, vol. I, p. 259), there is a chapter on the West Indian balsam in which the method of extraction is described in much the same terms as by Ricci. The balsam of Tolu, which Acosta speaks of as the best, is the product of a Leguminous tree called Myroxylon toluiferum, though other balsams seem to be got from species of Amyris. He mentions various places in America whence it was obtained, but none exactly agrees with Ricci's locality. The latter cannot have been quoting Acosta, whose book only came out in I590, unless the legend was added to the later editions of the map. He may, however, have been acquainted with Monardes' 'Historia medicinal . . de nuestras Indias Occidentales' (1574), which is quoted by Acosta. (The above information has been kindly supplied by Mr. Heawood.)

Mount Pei-tll-hsi (Potosi) is marked in its correct position somewhat north of the Tropic, but the legend, "there are many silver-mines in these mountains," appears to refer to another range of mountains further south.

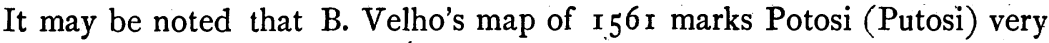
prominently just east of the Andes.

Pa-ta-wên or Country of Giants (Patagonia): the inhabitants of this country are not more than Io feet high. Both males and females paint their faces with all sorts of colours by way of ornament.

In a South American map engraved by J. van Doetichem about I 594 Plancius gives pictures of the Patagonians and says they were "ad summum" ro feet high. The imaginary river Orases is very conspicuously marked by Ricci, who calls it Ho-la-fo, the last syllable of which is puzzling.

The next legend, in the Pacific off the coast of Chile, affords further internal evidence as to the date of the map :

In olden days nobody had ever known that there were such places as North and South America or Magellanica. But a hundred years ago Europeans came sailing in their ships to parts of the sea-coast, and so discovered them. Howbeit, these countries are so vast, and the inhabitants so savage and cunning, that even now all the kingdoms in the interior, with their manners and customs, have not yet been explored.

The lapse of a hundred years from the time of Columbus brings us down to $\mathrm{I}_{52}$ at least, but Ricci may have been speaking in round numbers. A more precise indication of date is contained in the following (on the supposed continent of Magellanica):

$M o-w a-l a-n i$ (Magellan) was the name of a native of Fu-lang-chi (Portugal) who, sixty years ago, first passed through these straits and reached this land. 
Hence European scholars have named the straits, the sea (South Pacific), and the land after him.

Magellan passed through the straits and entered the Pacific in 1520 , so that this legend undoubtedly stood in the Shiuhing or ${ }^{584}$ edition of Ricci's map.

Huo-ti, "Fire Land" or Tierra del Fuego, is placed, in accordance with the other maps of the period, on the southern continent, a little to the south-west of the Straits.

This must conclude our present survey of the World Map. It seems to me fairly evident that it was not based on any single European map, but was a composite production drawn from various sources, including Ortelius, Mercator, and, for the later editions, particularly Plancius. Further search in Ramusio and other contemporary writers would doubtless throw more light on some of the legends and place-names, especially those not given by Plancius.

The origin of the Ambrosiana Map still remains a mystery, though Mr. Baddeley's opinion that it cannot be a copy of any of the editions of Ricci's World Map is fully borne out in the translations given above. I am even inclined to doubt whether Ricci himself had any hand in its production. A comparison of some of the features in the two maps, in addition to the dissimilarities already pointed out, will be the best way to make clear my reasons for this view.

\section{Ambrosiana Map.}

Nova Zembla (Hsin-tsêng-la) is shown as part of the mainland, with a large island to the north-west.

Muscovia is north of the Caspian (called "Northern High Sea"). tion).

Tu-êrh-ko (Turkey, eastern por-

Euphrates and Tigris are hardly distinguished.

Persia (Po-êrh.hsi-ya) is marked in large type, and correctly placed.

A long river traverses Central Asia ; rising north of the Shifting Sands, it passes through Hui-hui (Mohammedan Turkestan) south of Samarkand, and enters the south-east corner of the Caspian. (This may have been derived from a confusion of the Oxus with the Tarim, though the latter flows from west to east.)

\section{Ricci's World Map.}

Is an enormous island (Hsin-tsêngpo-la). A number of other large islands are scattered at random throughout the Arctic Ocean.

Is north of the Sea of Azov, and written with different characters. The Caspian extends much further east.

The name does not occur.

Both rivers are well shown, though running north and south.

Po-ssü (the usual Chinese name) is in small type, as if it were merely an unimportant district.

This river disappears, its place being taken by two shorter rivers, the northern and longer one flowing from the region of Sha-chou and entering the Caspian on the north, the other flowing straight from $P^{\prime} u$-chang $\mathrm{Hai}$ (Lop-nor) into the eastern part of the Caspian. 
The Indian peninsula is marked Yin-ti-ya.

The Indus (Tien-chu $H o$ ) flows nearly east and west.

Ceylon is called Tsê-i-lan.

Philippines are chiefly represented by Luzon.

Borneo is given in the Chinese form, $P^{i} \mathrm{v}-n i$.

Moluccas are called $M a-l u$.

New Guinea is shown as an island. "Java the Less" is not marked.

The Bering Straits are narrow, and much too far south.

The Nile is $N i-l u$.

Abyssinia is marked along the coast of the Red Sea.

Pa-êrh-pa-li-ya (Barbary) is written across Cyrenaica and Tripoli.

North Atlantic is divided into "Great Eastern Ocean" off America, and "Great Western Ocean" off Europe. "North Passage" in western Atlantic, and "South Passage" off south-west coast of Africa.

The "Sea of Libya" extends from the Gulf of Guinea to the Cape.

The Pacific is divided into "Small Eastern Ocean" off California, "Southeastern Sea" near the South Land, and T'ai-p'ing Hai (Great Peaceful Sea) a little east of the latter, off the coast of South America.

Name "California" does not occur. The peninsula is called "Promontory of the Cross."

Chile is "Chih-lê country."

The imaginary Orases River is not marked.
Marked Ying-ti-ya, the first two characters being different.

Shên-tu Ho, direction approximately correct.

Called "Hsi-lang Island."

Many large islands, mostly imagi. nary, are added to the group.

Po-êrh-ni-ho (all the characters different).

Ma-lu-ku Ti-fang. (It looks as if $k u$, which means "ancient," had been omitted in the Ambrosiana under the impression that it was an adjective qualifying $T i$-fang, " region.")

New Guinea is part of the southern continent, and "Java the Less" a large island.

Are of enormous width.

Nile is Ni-lo. The whole lake and river system of Africa is different in many respects.

A long way inland to the south. west.

The name does not occur. Barca and "Little Africa" in its stead.

"Great Western Ocean" off coast of Spain, Ho-chê-ya-no-ts'ang (Ocean Sea) in mid-Atlantic. North and South Passage not marked.

This part of the Atlantic is un. named.

"Great Eastern Ocean" off California, "South-eastern Sea" just below the Equator, "Sea of Magellan" corresponding to T"ai-p'ing Hai, and Ning Hai (Sea of Tranquillity) to "South-eastern Sea" of Ambrosiana.

Both these names occur.

Chih-li.

Very conspicuously marked.

We see that in some points the Ambrosiana is superior, in others inferior to Ricci. The difference in transliteration throughout is quite remarkable: thus, the Ambrosiana gives a rendering of the European syllables for Persia, but a shorter Chinese form for Borneo, while the R.G.S. map does exactly the reverse. On the assumption that Ricci was 
the author of both maps, it is very hard to understand why he should have made such capricious alterations. Again, the accuracy with which Ricci delineates Japan forbids us to suppose that he could have produced the Ambrosiana map later than 1602. But it seems equally improbable that, after making New Guinea an island and deleting the river Orases in South America, he should have reintroduced these errors in the third edition of his World Map. I am forced to the conclusion, then, that the Ambrosiana Map was not the work of Ricci at all.

Note by Mr. Heawoon.-The above divergences between the Ambrosiana and R.G.S. maps are certainly interesting, but are they not after all just what we should expect to find, even if the former were Ricci's work, in whole or in part? Dr. Giles has made it clear to what an extent Plancius' great map of 1592 was followed for Ricci's later editions (including our own map), but it was not in existence when the first edition appeared, and could hardly have been in Ricci's hands for some time (possibly several years) after its publication. No map made by him about $\mathbf{1} 592$ could possibly show the features of the 1602 map due to Plancius. As Dr. Giles has shown, Ricci "was not thoroughly conversant with the Chinese language" when he began making maps, and had to trust to an interpreter for the translations which, as he says, "could not be free from mistakes," so that differences of transliteration between earlier and later maps need surely cause no surprise. With the data then existing, the less correct representation of New Guinea in 1602 would be rather an evidence of up-to-dateness than of inferiority in the 1602 map. Both versions depended merely on guesswork on the part of the European map-makers, and it was precisely Plancius who held the view (as against the representation of Mercator and Ortelius) that New Guinea was probably connected with the southern mainland; so that a map based on his would be bound to show such a connection. Ricci was in fact, in all his maps, mainly following what seemed to him the best authority for the time being. Thus in omitting the Orases river in about $\mathbf{I} 592$ he would only have been following Ortelius, whose atlas we know to have been in the possession of the Fathers.

\section{GERMAN WAR MAPS AND SURVEY}

\section{Arthur R. Hinks, M.A., F.R.S., Sec. R.G.S.}

$7 \mathrm{HE}$ last four years have seen great progress in the art of mapproduction for war and in the application of survey to the improvement of gunnery. On the side of the Allies several quite new and most interesting methods have been brought to high perfection; but it has been forbidden to discuss at our meetings or deal in the Journal with mapping from air-photographs, sound-ranging or flash-spotting: three developments that have contributed much to the success that we have won, and deserve a high place in the scientific history of the war.

During a recent visit to France with the Chief of the Geographical Section, I was allowed by the kindness of the General Staff to study the British methods and to compare them with the German, as revealed in captured material ; and though it is still impossible to say anything of British methods, I am allowed to put together the following notes on the performance of our enemy after four years of war. 